\title{
CONTROLLING OBLIGATION TO MAKE REFERENCES FOR PRELIMINARY RULINGS: RECENT CASE LAW OF EUROPEAN COURTS
}

\section{UZRAUGOT PIENĀKUMU PIEPRASĪT PREJUDICIĀLUS NOLĒMUMUS: JAUNĀKĀ EIROPAS TIESU PRAKSE}

\author{
Arnis Buka, Dr. iur. \\ Assistant Professor at the Department of International and European Law, \\ Faculty of Law, University of Latvia
}

\section{Lolita Bērziņa, Dr. iur. cand.}

Lecturer at the Department of International and European Law, Faculty of Law, University of Latvia

\section{Kopsavilkums}

Eiropas Savienības tiesības noteic, ka Eiropas Savienības dalībvalstu augstākajām tiesām konkrētos gadījumos ir ne vien tiesības, bet arī pienākums vērsties ar lūgumu pēc prejudiciālā nolēmuma pie Eiropas Savienības Tiesas. Gan Eiropas Savienības Tiesa, gan arī Eiropas Cilvēktiesību tiesa pēdējo gadu laikā ir analizējusi situācijas, kurās šis pienākums, iespējams, ticis pārkāpts. Saskaṇā ar Eiropas Savienības Tiesas aktuālāko praksi augstākās tiesas nevēršanās pēc prejudiciālā nolēmuma var novest pie pārkāpuma procedūras. Savukārt Eiropas Cilvēktiesību tiesa šķietami sašaurinājusi tiesību uz taisnīgu tiesu uzliktās prasības prejudiciālo nolēmumu kontekstā. Raksta autori argumentē, ka Eiropas tiesu prakse gan ir viesusi zināmu skaidrību augstāko tiesu pienākuma kontekstā, bet tajā pašā laikā radījusi arī vairākus papildu jautājumus par atsevišķiem šì pienākuma aspektiem.

Keywords: EU law, the Court of Justice of the EU, preliminary rulings, European Commission, European Court of Human Rights

Atslēgvārdi: ES tiesības, Eiropas Savienības Tiesa, prejudiciālie nolēmumi, Eiropas Komisija, Eiropas Cilvēktiesību tiesa

Article 267 of the Treaty on the Functioning of the EU (TFEU) in defining the preliminary rulings procedure makes a distinction between two different categories of national courts - the courts of the last instance and other adjudicating bodies, whose decisions are subject to appeal. Regarding the second, it is only an option and not an obligation to use the preliminary rulings procedure, but for the first, it is a duty to refer the issues on the validity or interpretation of the EU law to the Court of Justice of the European Union (CJEU). 
The text of the Article 267 of the TFEU does not expressly provide any exceptions to the duty of courts of last instance to make the reference. However, in its famous CILFIT judgment the CJEU itself admitted that there are three exceptions, when the national courts of last instance are legitimized to avoid the reference on the EU law issues, namely:

- the question raised is irrelevant for the outcome of the case

- the EU law provision in question has already been interpreted by the CJEU

- the correct application of the EU law is so obvious as to leave no scope for any reasonable doubt. ${ }^{1}$

Although the obligation to make reference seems rather clear-cut, there is a great deal of uncertainty regarding possible means of control over those national courts of last instance that might try to avoid their duty to make the reference to the CJEU. ${ }^{2}$ The only means of control that were recognized by the CJEU more than a decade ago is state liability for the breach of the EU law. The principle of the state liability was extended to the actions of the courts of the Member States by the Köbler judgment in 2003, in which the CJEU stated that non-compliance with the obligation to refer matter to CJEU is a condition for the state liability. ${ }^{3}$ Constitutional courts in several EU Member States also recognize the breach of right to fair trial, if the court of last instance of that Member States violates the obligation to make a reference for a preliminary ruling to the CJEU. ${ }^{4}$

Apart from the state liability and the complaint to the constitutional court, there are two additional possible means of control over the duty to make reference to the CJEU - infringement actions against the EU Member States that are initiated by the European Commission (Commission) under the Article 258 of the TFEU and the applications of the individuals to the European Court of Human Rights (ECHR) claiming breach of the right to fair trial in the Article 6 of the European Convention on Human Rights (Convention). The analysis of the newest case law in those areas is the focus of the present paper.

\section{CJEU: Infringement actions against Member States}

\subsection{Historical development}

The right of the Commission to initiate infringement procedure in accordance with the Article 258 TFEU is one of the possible means to ensure that the courts of last instance in Member States observe the duty to make the reference for the preliminary ruling. Until 2018, there had been no judgments in the infringement proceedings against the Member States resulting from the decisions of the national courts, yet the growing activity of the Commission in the $21^{\text {st }}$ century already suggested that the Commission is ready to make steps in the direction of controlling the observance of the Article 267 of the TFEU.

1 CJEU judgment of Okt 6, 1982 in the case 283/81 CILFIT.

2 Fundamental research in this area was done by the doctoral thesis of Zane Sedlova "Legal Remedies for the Failure to Make a Preliminary Reference" (Univesity of Latvia, 2016).

3 CJEU judgment of Sept 30, 2003 in the case C-224/01 Köbler, para 55.

4 The most extensive case law in that regard exists in Germany. On this also see, e.g., Valutyte R. Legal consequences for the infringement of the obligation to make a reference for a preliminary ruling under constitutional law. Jurisprudencija, 2012, Vol. 19(3), p. 1175. 
The Commission already has proved that it will not tolerate any legislative measures that might endanger proper functioning of the preliminary rulings procedure. ${ }^{5}$ Furthermore, the Commission has stated that a Member State's failure to fulfil obligations under the EU law may be established under Article 258 of the TFEU, whatever the agency of that State whose action or inaction is the cause of the failure to fulfil its obligations, even in the case of a constitutionally independent institution. ${ }^{6}$ In several cases, Commission started the actions against the Member States because the infringement of the EU law occurred due to the interpretation of the national law by the national courts. ${ }^{7}$ Historically, active informal communication with the governments also took place with a view to ensure that, at the very least, the government should advocate in cases before the national supreme courts and should defend a position, which is substantively consistent with the decisions of the CJEU. ${ }^{8}$

However, until 2018, the infringement procedure by the Commission could not be regarded as an effective tool of control, because the Article 258 of the TFEU so far in the case law of the CJEU in respect of administrative breaches of the EU law has been used only in cases of repeated breaches. Therefore, by analogy, one could conclude that most likely the CJEU within the infringement procedure under Article 258 of the TFEU will be ready to declare the breach of the Article 267 of the TFEU only in cases of a constant tendency in the national case law. ${ }^{9}$

\subsection{Recent case law}

Yet, at the end of the 2018, the CJEU radically changed the approach and took much more decisive position on the matter with the judgment on October 4, 2018 in the case C-416/17 Commission v. France. ${ }^{10}$

The substance of the case was rather complicated and failure of the French courts to make a reference for the preliminary ruling to the CJEU was only last step in the judgment. The main dispute of the case concerned the French tax regime that for taxation purposes treated the distribution of dividends favourably, if they originated from a subsidiary established in France, but did not offer that option, if those dividends originated from a subsidiary established in another Member State. Initially, those rules were subject to litigation in 2009, when the Conseil d'État (Council of State) made a reference to the CJEU for the preliminary ruling as to whether Articles 49 TFEU and 63 TFEU (free movement of establishment and capital) precluded such legislation. In the case Accor in 2011, the CJEU found these rules contrary to Articles 49 and 63 TFEU. ${ }^{11}$

5 7th Annual Report on monitoring the application of Community law. Annex VI. Application Of Community Law By National Courts, Official Journal, 1990, C 232, p. 54.

${ }^{6} \mathrm{CJEU}$ judgment in the case 77/69 Commission v Belgium; once more confirmed in case C-129/00 Commission v. Italy.

7 E.g., CJEU judgment in the case C-382/92 Commission v. United Kingdom; also CJEU judgment in the case C-154/08 Commission v. Spain.

8 16th Annual Report on monitoring the application of Community law. Annex VI. Application Of Community Law By National Courts. Official Journal, 1999, C 354, p. 187.

9 Although one could argue that in the case C-154/08 Commission v. Spain CJEU admitted theoretical possibility to declare breach of the Article 258 of the TFEU because of the singular judgment of the national court.

${ }^{10}$ CJEU judgment of Oct 4, 2018 in the case C-416/17 Commission v. France.

11 CJEU judgment of Sept 15, 2011 in the case C-310/09 Accor. 
The matter returned to the Conseil d'État, which subsequently, in two judgments rendered in 2012, established the conditions for the reimbursement of the unlawful payments. Doing so, it partially ruled on a point that had not been addressed by the CJEU in Accor, the taxation of sub-subsidiaries established in another Member State. No such claim had been raised before the Conseil d'État in 2009. It is important to note that right before the Conseil d'État issued these judgments the CJEU decided precisely this point in another case related to the UK tax regime (case C-35/11 Test Claimants). ${ }^{12}$ The French Supreme Court decided to depart from this ruling without making a second preliminary reference to the Court.

Following the Conseil d'État decisions, the Commission received a number of complaints claiming that the conditions for reimbursement of advance payments were contrary to the EU law, which ultimately led it to bring an action against France for failure to fulfil its obligations based on the Article 258 of the TFEU. However, the most striking feature of this case is that the Commission not only argued that France had breached TFEU provisions on the free movement of establishment and capital, but also the Article 267 of the TFEU (by failing to make a reference to the CJEU).

Even more striking is the fact that, regarding the point of France's breach of the EU law by failing to make a reference for the preliminary ruling, the CJEU agreed with the Commission. The Commission in its application put forward several arguments that, in their opinion, indicated the existence of the breach of the Article 267 of the TFEU. The Commission started with the general observation that "the compatibility with EU law of the restrictions arising from the judgments of the Conseil d'État appears doubtful, at the very least" and continued that "the mere fact that the Commission has a different understanding of the principles established in the judgment of [the CJEU] from that expressed by the Conseil d'État shows that the solutions arising from those judgments cannot enjoy a presumption of compatibility with EU law". ${ }^{13}$

The argumentation of the CJEU was also very brief. The CJEU, firstly, pointed out that the Conseil d'État clearly "chose to depart from the judgment"14 of the CJEU in the C-35/11 Test Claimants. Secondly, CJEU observed that the Conseil d'État adopted the position, "which is at variance with that of the present judgment", ${ }^{15}$ and this is an indication that there certainly exists at least reasonable doubt concerning the interpretation of the EU law.

One the one hand, it is a good and welcome development in the case law of the CJEU. The preliminary reference procedure is fundamental to the EU legal order and its decentralized judicial model whereby national courts are ordinary judges of the EU. In that framework, a failure to make a preliminary reference by a national court of last instance when necessary threatens the uniform application of EU law. The obligation contained in the third paragraph of the Article 267 of the TFEU, as expressed by the CJEU, prevents a body of national case law that is not in accordance with the rules of EU law from being established in any of the Member

\footnotetext{
12 CJEU judgment of Nov 13, 2012 in the case C-35/11 Test Claimants.

13 CJEU judgment of Okt 4, 2018 in the case C-416/17 Commission v. France, para 102.

14 Ibid., para 111.

15 Ibid., para 112.
} 
States. The present judgment reinforces this obligation and clearly signals that the Commission and the CJEU will carefully police it. ${ }^{16}$

On the other hand, the judgment leaves some questions still to be answered in the future. Firstly, the brief style of the argumentation of the CJEU does not explain particularities as to when exactly the Article 258 might be used to combat non-reference to the CJEU: does it hold only if there is a clear line of existing case law from the CJEU and national court is departing from that case law? Secondly, in this case, the breach of the Article 267 of the TFEU on the part of the judiciary was only one of the claims of the Commission. Therefore, it remains to be seen whether the Commission will be successful in bringing the actions under the Article 258 of the TFEU solely on the basis that national judiciary has breached the Article 267 of the TFEU. Moreover, thirdly, the consequences of the judgment on the national level are unclear, as well - does such a conclusion of the CJEU give rise to the possibility to re-open the case? Alternatively, at the very least, does this judgment of the CJEU serve as "bullet-proof" evidence if somebody wants to start an action against the France and claim damages?

\section{ECHR: non-reference to the CJEU as a breach of the right to fair trial}

\subsection{Historical development}

Another possible means of control over the duty to make references for the preliminary rulings is the application of the individual to the ECHR with claims that non-reference to the CJEU breaches of the right to fair trail enshrined in the Article 6 of the Convention. Initially, the ECHR in its case law adopted very cautious approach - despite many applications from individuals, for several decades there were no judgments on substance, only several dozens of decisions on inadmissibility. The ECHR held its ground with the constant position that the nonreference in particular case was not sufficiently arbitrary to qualify it as a breach of the right to fair trial. ${ }^{17}$

However, in 2014 the ECHR delivered the first judgment in Dhabi v. Italy case, in which the state was found in breach of the Article 6 of the Convention because of refusal of a national court of last instance to make a reference to the CJEU. ${ }^{18}$ This case was followed by similar judgment in Schipani v. Italy case one year later. ${ }^{19}$ In both of those cases, the approach taken by the ECHR was quite straightforward, establishing that the breach of the Article 6 of the Convention occurs, if the national court of last instance provides no argumentation at all when justifying its decision not make a reference for the preliminary ruling.

16 Delhomme V., Larripa L. C-416/17 Commission v France: failure of a Member State to fulfil its obligations under Article 267(3) TFEU. Available at: https:/europeanlawblog.eu/2018/11/22/c-416-17commission-v-france-failure-of-a-member-state-to-fulfil-its-obligations-under-article-2673-tfeu/ [last viewed on April 1, 2019].

17 See Valutyte R. State liability for the infringement of the obligation to refer for a preliminary ruling under the European Convention on Human Rights. Mykolas Romeris University periodical reviewed research papers "Jurisprudence", 2012, Vol. 19(1), pp. 7-20.

18 ECHR judgment of Apr 4, 2014 in the case Dhabi v. Italy (application no. 17120/09).

19 ECHR judgment of Jul 21, 2015 in the case Schipani v. Italy (application no. 38369/09). 
Those judgments were quite revolutionary in their nature. Still, the particularities of the ECHR approach to the extent of the duties of the national courts in those judgments felt slightly ambiguous. For example, the ECHR did not provide an explanation that would sufficiently detail the duty of the national court to give argumentation on non-reference to the CJEU. Additionally, in those two judgments the ECHR took into account the responsibility of the applicant to substantiate a request for a preliminary ruling with relevant arguments. Yet, the ECHR did not pay much attention to the degree of detail of the requests, so it was not very clear what exactly the ECHR expected from the parties' requests. ${ }^{20}$

\subsection{Recent case law}

Since the judgment in Schipani v. Italy case in 2015, so far there were no more judgments of the ECHR that would find the breach of the Article 6 of the Convention because of non-reference to the CJEU by the national court. At the same time, the applications to the ECHR in that regard keep coming, and the case law of the ECHR is under development. Thus, in 2018, ECHR delivered an interesting judgment that follows up on the issues that were left unaddressed by Dhabi and Schipani cases.

The judgment was delivered in the case Baydar v. Netherlands. ${ }^{21}$ The case is compelling already at the admissibility stage, since the government of the Netherlands argued that the applicant had failed to exhaust all the available domestic remedies by not bringing an action for damages against the state before the civil courts on the grounds that the Supreme Court's judgment was unlawful (the possibility of such action is recognized in the EU law by the Köbler line of cases $^{22}$ ). However, the ECHR dismissed those objections by stating that "the remedy was an effective one, available in theory and in practice at the relevant time". ${ }^{23}$ Nevertheless, this position of the ECHR might have an important impact in the future: if there will be more successful claims against EU Member States for damages in accordance with the Köbler line of cases, action for damages might become a prerequisite for such cases to be adjudicated by the ECHR.

Furthermore, the judgment in Baydar case addresses the issue on how extensive the argumentation of the national court should be when that court is not referring for the preliminary ruling. In comparison with the previous case law of the ECHR on the matter, this case was specific, since the decision of the Supreme Court of Netherlands was very short in general, because the applicant's appeal in cassation, including his request for a referral to the CJEU for a preliminary ruling, was based on a summary reasoning.

The ECHR started addressing the issue by recalling that it has previously held acceptable under Article 6 of the Convention for national superior courts to dismiss a complaint by mere reference to the relevant legal provisions governing such complaints, if the matter raises no fundamentally important legal issues. ${ }^{24}$ The ECHR then continues by stating that it accepts that the summary reasoning

\footnotetext{
${ }^{20}$ Krommendijk J. 'Open Sesame!': Improving Access to the ECJ by Obliging National Courts to Reason Their Refusals to Refer. European Law Review, 2017, Vol. 1, pp. 46-62.

${ }^{21}$ ECHR judgment of Apr 24, 2018 in the case Baydar v. Netherlands (application no. 55385/14).

22 CJEU judgment of Sept 30, 2003 in the case C-224/01 Köbler.

${ }^{23}$ ECHR judgment of Apr 24, 2018 in the case Baydar v. Netherlands (application no. 55385/14), para 35.

24 Ibid., para 46.
} 
contained in such a dismissal implies an acknowledgment that a referral to the CJEU could not lead to a different outcome of the case. Therefore, the Article 6 of the Convention has not been breached.

Such conclusions of the ECHR in the Baydar case significantly narrow down the previous approach of the ECHR in Dhabi and Schipani cases, where the main criteria for the breach of the right to fair trial was lack of argumentation on the part of the national court regarding the reference. With Baydar, the ECHR basically retreats from stricter approaches in the Dhabi and Schipani cases and tries to limit the scope of Article 6 of the Convention in cases of non-reference to the CJEU for the preliminary ruling.

\section{Conclusion}

1. The last five years witnessed the rise of determination on the part of both the CJEU and ECHR to monitor situations where national courts of last instance avoid references to the CJEU for the preliminary rulings.

2. Comparing both European courts, the CJEU definitely remains the leading judicial body in that context, as the ECHR is not directly connected with application and interpretation of the EU law and can evaluate the nonreferences only from the narrow point of the right to fair trial. Moreover, the recent judgment of the ECHR in the case Baydar v. Netherlands indicates that the ECHR is willing to accept a very wide margin of discretion on the part of national courts and might declare the breach of right to fair trial only in extremely exceptional cases.

3. On the other hand, the CJEU with the judgment in the case Commission v. France certify determination to put more pressure on national courts to avoid non-references for the preliminary rulings in cases where those references should have been made.

4. Even more, from the perspective of the efficiency, it seems that the Commission due to the specifics of its functions is the only institution, which is capable to ensure real control mechanism over correct application of the preliminary rulings by the national courts of the last instance. Therefore, improvement of the effectiveness of the Commission as the main body that controls correct application of the preliminary ruling procedure in the national courts of last instance is of utmost importance. The CJEU in its case law should uphold the possibility to start an infringement procedure even in the case of singular incorrect judgment from the national judiciary. 